\title{
Tagungen und Kongresse
}

20.-24. 6. 1984

28.-30.6. 1984

25. 6. - 3. 7. 1984

8.-12. 7.1984

19.-26. 7. 1984

23. 7. -26.7 .1984$

26. -28.9 .1984$

22. -26.10 .1984$

1.-3. 11.1984
Internationales Olympia-Symposium „Sport, Kunst und Wissenschaft, vereint durch die Humanitas".

Kontakt: Generalsekretär der IOV, Waldhornstr. 107, 8000 München 50.

Die Schülerperspektive in der sportpädagogischen Unterrichtsforschung. Symposium der Kommission „Schulpraktische Studien-Unterrichtsforschung ${ }^{*}$ der DVS in Göttingen.

Kontakt: G. Köppe, Fichtenweg 14, 3414 Hardegsen.

Olympismus und Erziehung.

6. Intern. Lehrgang für Pädagogen an der Internationalen Olympischen Akademie.

Kontakt: Nationales Olymp. Komitee für Deutschland, OttoFleck-Schneise 12, 6000 Frankfurt/M.

Physical Activity, Aging and Sports. II. Intern. Conference, organized by the Center for the Study of Aging. West Point, N. Y., USA.

Kontakt: S. Harris, Center for the Study of Aging, 706 Madison Avenue, Albany NY 12208.

1984 Olympic Scientific Congress, an International Sport and Scientific Conference, held in Cooperation with the United States Olympic Committee and the 1984 Summer Olympic Games.

Kontakt: University of Oregon, Eugene, Oregon/USA (Dr. D. Tripps, 1984 Olympic Scientific Congress, College of Human Development and Performance, University of Oregon, Eugene, Oregon 97403-1273, USA, Tel. $503-686-41$ 14).

Pre-Olympic Games International Symposium "Children to Champions", Northridge/Los Angeles/USA.

Kontakt: Dr. John Callaghan, Department of Physical Education, University of Southern California, Los Angeles, CA 90089-0652, USA.

6. Sportwissenschaftlicher Hochschultag der DVS: „Handeln in Sport". Universität Bremen.

Kontakt: Organisationsausschuß 6. Sportwissenschaftlicher Hochschultag, Prof. Dr. G. Hagedorn, Studiengang Sportwissenschaft, Bad Gasteiner Straße, 2800 Bremen 33.

ICOSH Seminar 1984, Sport and Politics 1918-1940, Oslo, Norwegen.

Kontakt: Dr. A. Morgan Olsen, Norwegian College of Physical Education and Sport, Post Box 40, Kringsja, Oslo 8, Norway.

Sport und Ethik. Symposium der Sektion Sportsoziologie in der Deutschen Vereinigung für Sportwissenschaft in Bartholomä. Kontakt: G. Drexel, Institut für Sportwissenschaft, Universität Tübingen, Wilhelmstr. 124, 7400 Tübingen. 